\title{
Identity, Space and the Media: Thinking through Diaspora
}

Identité, espace et médias : une réflexion sur la construction diasporique Identidad, espacio y medios de comunicación: pensar a través de la diáspora

\section{Myria Georgiou}

\section{(2) OpenEdition}

Electronic version

URL: https://journals.openedition.org/remi/5028

DOI: $10.4000 /$ remi.5028

ISSN: $1777-5418$

\section{Publisher}

Université de Poitiers

\section{Printed version}

Date of publication: 1 February 2010

Number of pages: 17-35

ISBN: 978-2-911627-54-5

ISSN: 0765-0752

\section{Electronic reference}

Myria Georgiou, "Identity, Space and the Media: Thinking through Diaspora", Revue européenne des migrations internationales [Online], vol. 26 - $n^{\circ} 1$ | 2010, Online since 01 February 2013, connection on 14 April 2022. URL: http://journals.openedition.org/remi/5028 ; DOI: https://doi.org/10.4000/remi.5028 


\title{
Identity, Space and the Media: Thinking through Diaspora
}

\author{
Myria GEORGIOU*
}

\section{INTRODUCTION}

Space occurs as the effect produced by the operations that orient it, situate it, and temporalize it, argues De Certeau (1984); space is composed of intersections of mobile elements, assemblages and meeting points: space is a practiced place, De Certeau concludes providing a starting point for the present discussion. The keywords in De Certeau's definition of space capture the core qualities of the interconnected world that frame meanings of identity and culture in current times. How can we understand culture and identity at present, if not through mobility, immediate and mediated intersections and juxtapositions of difference? How can we understand situated identities if not through the practices that interconnect or interrupt human action in and across places? A spatial approach to identity and mediation provides the necessary cross-fertilization of these three concepts as, arguably, none of them can be fully understood if not through the other. In no other case is the close relation between space, identity and the media more obvious than in the case of diaspora. Diaspora is an exemplary case of cultural formation within the interconnected world - what I will here describe as a cosmopolitan world; diaspora captures human mobility and (re)settlement not as opposite points, not as cause and effect, but rather as co-existing elements of a world connected through flows and networks or, as Appadurai (1996) puts it, through scapes. What I argue in this contribution is that we need to record qualities of human mobility, of meetings and human assemblages and their interruptions in order to capture the meanings of diasporic and migrant identities - and as an extension, of cosmopolitan identities which are not exclusively owned by diasporas. Furthermore, I argue, we need to record some of the increasingly central qualities of culture: the mediated connections within and across space that provide human subjects information and communication for being and becoming. This paper offers a theoretical invitation to think through the relation of space, identity and the media.

* Lecturer, Dept of Media and Communications, London School of Economics and Political Science, Houghton Street, London WC2A AE, m.a.georgiou@Lse.ac.uk 
It learns from empirical studies and literature on diaspora, migration and the media as it develops a two part discussion. In the first section, a multi-spatial approach is proposed as a starting point for the study of culture, especially diasporic culture and identity. In this section, the spatial matrix for diasporic identity and media culture, which consists of the home, the city, the nation and the transnational space, is discussed. In the second part, the interconnections and co-dependence of identity, space and the media are presented, especially around two specific parameters: proximity and the redefinition of space through media consumption. Before moving to the main part of the discussion, the conceptualisation of space and diaspora the paper adopts and the main parameters of a spatial approach within cosmopolitanism are presented below.

\section{Defining space}

'[T]erritoriality has become an anachronistic delimitation of material functions and cultural identities; yet, even in the face of the collapse of traditional concepts of sovereignty, monopoly over territory is exercised through immigration and citizenship policies', argues Benhabib (2004: 5), explaining the tension between human and cultural transnationalism on the one hand, and state persistence on territorial boundedness and loyalties attached to it on the other. The political top down framing of identity insists on equating it to citizenship; both identity and citizenship in this context are singular and attached to the nation-state. However, and at the same time, for diasporic and migrant groups, but also increasingly for many cosmopolitan subjects, the attachment to a singular place and the grounding of identity to a single polity or community become increasingly irrelevant. How can an ideology of territorial being and belonging capture the connections of migrants with family in various continents, or their multilingual spheres of belonging developed through their travels? And to move even beyond diaspora, how can a territorial approach reflect the sense of belonging among participants in global social movements, or even among young people who share transnational Facebook or musical fandom cultures? Territoriality is indeed anachronistic but remains deeply rooted in political conceptualisations of identity; this is why formal citizenship remains (or has become reinvented to be) property of those having long and usually rooted into territory rights. At the same time, the cultural landscapes and the flows of people, technologies, and information suggest otherwise. As Appadurai argues 'people, machinery, money, images and ideas now follow increasingly nonisomorphic paths'(1996: 37) with speed, scale and volume that are (re-) defining culture on global level. The interconnected world relates more to Appadurai's scapes (1996) than to a stable political and bounded geographical zone. Flows and networks, captured in works such as those of Appadurai since the 1990s, have become further articulated in recent literature on cosmopolitanism.

The present discussion is influenced by the cosmopolitan analyses that provide the broader theoretical framework for thinking about space and identity. The conceptualisation of cosmopolitanism adopted here relates primarily to transnational mobility (elite and working class), the intensification of transnational politics that challenge the nation-state from below (through social movements' activities especially), migrant and diasporic cultural and political activities, and the changing 
cityscapes. Importantly, in the cosmopolitanism literature, the transnational and the urban have become more than just side-effects and results of globalisation. The increasingly diverse cities and the complex social action among migrants, diasporas and other groups marginalised in the national and supranational formations of citizenship and economic engagement are now recognised as fascinating and critical elements of our changing world. Sandercock speaks of cosmopolitanism as attached to cities of cultural difference and 'our intertwined fates' (2003: 182). Werbner (1999) discusses working class cosmopolitanism in relation to the mobility of people, cultural artefacts and products among diasporas, and Delanty (2000) argues that cosmopolitanism implies a world openness through which societies undergo transformation. As an analytical concept, cosmopolitanism is a category that captures the complexities of multiple forms of belonging and of heterogeneous and fragmented publics by challenging essentialist interpretations of identity and bounded communities, as well as assumptions about stable and ever present hierarchies that have indiscriminately defined social relations, politics and culture for more than a century (e.g. social and geographical divisions, meanings of citizenship, key elements of identity). Cosmopolitanism as a category, since its original formation, has recognised the importance of human mobility, boundary crossing and close encounters of difference for the production of meaning, identity and political action. As such, it can explain how those 'in charge' of time and space compression might drive change across boundaries, but also how - especially in times of global financial turmoil - they can also lose control; how those in the receiving side of power geometry (Massey, 1993) might drive elements of change in culture and politics, as observed for example in the emergence of heterogenous publics and the transformations of cities of the global north into cosmopolitan cities. 'Through a study of the history of spaces and an understanding of their heterogeneity, it became possible to identify spaces in which difference, alterity, and "the other" might flourish', explains Harvey (2006: 537).

Space can also and best frame analyses and interpretations of conflict and dialogue, especially as encountered in the intense juxtapositions of difference in (trans-) urban worlds (Beck, 2006; Harvey, 2006) and it can capture the links between the cultural and the political spheres of representation. If 'space is fundamental in any form of communal life', then space must also be 'fundamental in any exercise of power', argues Foucault (in Harvey, 2006: 538). Bourdieu also talks about a socially ranked geographical space (1979) and all these debates point towards one key quality of space as an analytical framework for studying cultural practice and identity; space is a framework that allows us to study identity through mobilities, meeting points, settlement/re-settlement, but also meaningful relations - including those of subordination, exclusion, and participation in publics and communities - as they emerge at the meeting of the political (e.g. formal citizenship) and the cultural (e.g. education, health, communication) spheres. In Lefebvre's words: '[t]he concept of space links the mental and the cultural, the social and the historical' (2003: 209). According to Lefebvre, space reconstitutes complex processes that include discovery (of new or unknown spaces, of continents, or, of the cosmos), production (of the spatial organization characteristic of each society) and creation (of landscapes, specifically the city (2003). Space is real and/or virtual and imagined; its natural substance and boundedness are increasingly challenged as permanent characteristics. 
The present paper suggests that we have to revisit space and think about it as a central category in relation to identity and representation in the context of diaspora, migration and the media research. In addition, it suggests that we need to adopt a cosmopolitan outlook that enables the development of conceptual frameworks and methodological strategies that allow us to record the significance of various spaces in their own standing and in their interconnections, so that we go beyond either/or (Beck, 2006) and we can analyse 'this and that' as well as the possible 'neither/nor'. The cosmopolitan outlook comes together with a (multi-)spatial approach to identity that unfolds a framework for this discussion. A cosmopolitan outlook brings with it the recognition of a number of complexities in the contemporary interconnected world, such as:

- The multiple spaces of belonging: all human subjects move between various spaces of belonging - physical and symbolic. Though not all individuals or groups enjoy the same levels of mobility (and in particular restrictions need to be taken into serious account, especially those relating to class, gender, sexuality, and age), the argument is that increasingly human subjects develop their sense of being and becoming in relation to the interconnected space, which they might experience or be excluded from.

- The transnational connections: Transnational mobility and the intensification of transnational politics challenge the nation-state from below and from above and many of the taken-for-granted assumptions around identity; migrant and diasporic cultural and political activities develop across boundaries and so does the sense of belonging to communities.

- The juxtapositions (and not just hierarchies and linear relations) of difference in the cosmopolis: The increasingly diverse cities and the complex social action among migrants, diasporas and other groups marginalised in the national and supranational formations of citizenship and economic engagement illustrate the significance of the physical - and more often than not, urban - points of contact in understanding identity, its meanings and its limitations.

- The complex systems of citizenship and belonging: Citizenship, cultural and political representation spill outside the bounded sphere of formal politics to include practices and experiences that give meaning to citizenship. Marginalized groups claim citizenship and assert simultaneous belonging in various communities, often including the nation, but also distant or transnational communities, such as diasporas. Understanding the complexity of citizenship is directly linked to understanding identity, as the links between cultural and political representation become increasingly blurred. Concepts such as flexible citizenship, multicultural or polycultural citizenship, or dissenting citizenship are only some of the propositions for recording the meeting of multiple belongings and representation.

\section{Thinking through diaspora}

By thinking through diaspora, we observe the qualities of space as lived and as imagined, as context for identification and struggle, as dependent on memory, experience and ideology of deterritorialization and reterritorialization, of mobility and of contact or interruptions of contact with old and new others. Diasporic populations 
live within specific locales - urban places especially - and in national and transnational spaces. The social interaction and communication within the diasporic communities, among dispersed sections of the same diaspora and beyond the limits of diasporic communities, all take place in space. Some of these spaces - also defined as ethnoscapes and mediascapes by Appadurai (1996) - are grounded in very specific places - such as the neighbourhood - while others exist virtually and in non-places (Urry, 2000). Social interaction and relations are no longer dependent on simultaneous spatial co-presence; there are also relations developing with the absent other through mediated communication. When place seizes from being a singular and restricting context for social relations, the experience of time and space becomes distanciated (Giddens, 1990) and diasporic communities break off the specificities and singularities of place and expand their potentials for communication and community. In this context, there is less and less a possibility for a neat equation between culture, community and geography (Gillespie, 1995) and increased potentials for 'imaginative geography and history' (Said, 1985).

Cultural mobility, imagined or real, is recognised by Cohen as an element of the growing relevance to diaspora, not only for understanding its own qualities but also for understanding the wider connections and flows of people and technologies at present time. Diaspora refers to people who cross boundaries and who settle in locations different to those of their origins. Diaspora is also a category that implies multiple connections across space and flows of ideas and information beyond a singular nation. Work done within studies of transnationalism has contributed in thinking of diasporas as networked, transnational formations (cf. Portes, 1997; Vertovec, 2009). Within this literature diasporas as transnational communities have been discussed for their contribution in thinking beyond the binary opposition global/local. Diasporic cultures and political activity, emerging across geographical boundaries and taking specific forms in local domains have also attracted interest across the social sciences and have been discussed as forms of counter-hegemonic practices and alternative forms of (selective) community participation and rearticulation of identities (Sandercock, 2003; Schiller et al., 1995; Werbner, 2008). Diasporic transnationalism is less about place and more about space. It is less about the boundary and more about imagination. It invites us to consider the possible emergence of contradictory yet viable forms of transnational imagined communities, especially through selective and partial participation. As such, diaspora can arguably become a metaphor for life and identity in cosmopolitan times. As a metaphor it captures the human connection across boundaries and growing mediation. Media, telephony and digital technologies have altered transnational communication practices in the last couple of decades to such an extent as to allow daily and vast transnational exchanges online, on the phone and on television screens. Cohen proposes a redefinition of diaspora in the light of these changes:

"Nowadays, with the increased use of the term to describe many kinds of migrants from diverse ethnic backgrounds, a more relaxed definition [of diaspora] seems appropriate. Moreover, transnational bonds no longer have to be cemented by migration or by exclusive territorial claims. In the age of cyberspace, a diaspora can, to some degree, be held together or re-created through the mind, through cultural artefacts and through a shared imagination" (1997: 26). 
Cohen's proposal offers an interesting challenge, at least in thinking about transnational connections as qualities not only owned by those who have experienced migration, not exclusively owned by the elites either, but also as qualities of human communication attached to the cosmopolitan condition. Looking at the wider transnationalisation that affects the life of most human subjects at present is not an invitation to put social divides, injustice and hierarchies aside, but rather, it is an invitation to consider connections (or lack of and restrictions to connections) across space as key elements of identity and community.

Transnational connections are not singularly and uniquely properties of diasporas and as such this discussion has wider implications. At the same time, and in order to appreciate the significance of diaspora, we also need to look at diasporic identities in their specificity. Diasporic identities are shaped in different spaces, which are interconnected and sometimes distinct and competing. Each different space is attached to a shared sense of belonging and to a sense of longing and shared memory of uprooting (Cohen, 1997). Diasporic identities depend on shared myths and memories, as well as upon a sense of belonging in an imagined community which has some continuity and relevance across time and space (Georgiou, 2006). For diasporic identity, spatiality is of particular importance, especially as mobility and resettlement shape both experience and imagination. Diasporic mobility and resettlement connect at least two places, while the simultaneity of migration of a group to more than one places creates the conditions for networked relations across places. Diasporic identities then become complex and changing systems and the position that individuals or groups take in spatial matrices define many of the elements of the content of those identities. On the one hand, the mobility/resettlement apparatus and on the other, the specific spaces that diasporic subjects occupy (in urban or rural places; through physical or only mediated journeys; in social positions of marginality or relative prosperity) play a key role in defining the limits and meanings of diasporic identities.

\section{A MULTI-SPATIAL APPROACH}

'Home is no longer one place, it is locations' (bell hooks cited in Amin and Thrift, 2002: 46)

Space is not singular; it brings together into meaningful relations and formations places and practices. Space also carries social meanings - and these are always plural. The meanings of space are shaped in contexts of continuities, links and conflicts. The home, the public, the city, and the national, in its interconnections with the transnational space form layers of the spheres of belonging; they together form the puzzle of the context where social relations, communication and action take place and shape the meanings of identity and community. Each of these elements of space is an autonomous node and each has its own dynamics, its morality, economy, and its social and cultural meanings. The home or the city are not only defined in relation to the meanings of identity; they also play multiple roles in the broader economic and cultural contexts of the locale, the national and the trasnational context. However, in relation to meanings of identity and community they have a specific significance both in their autonomy and in their interconnection. 'Knowing where we are is as important as knowing who we are, and of course the two are intimately connected' argues Silverstone (1999: 86). 
The domestic, the local, the public, the urban, the national and the transnational form an interconnected spatial matrix, where possibilities for belonging, for choosing not to belong and for combining belonging in multiple communities emerge. These are spaces where the struggles for inclusion and exclusion are not between two sides: these of the powerful and the subordinate but between different powerful and subordinate actors. Media actively get involved in the practices and ideologies of what it means to belong, of what identification with a group and a community consists of, what the symbols of the imagined self, the Other and the community are and how the boundaries around communities and places are appropriated. In addition, the geography of social relations is changing as much as the relations between spaces. They often stretch out over defined spaces; yet, and as Massey (1993) argues, social relations, movements and communication change, but they meet in places that become unique points of their intersection. This section briefly introduces the main spaces where diasporic life unfolds.

\section{Home}

Home - both in its real shape as a place, as well as in its symbolic imaginary form - provides the initial and emotional parameters for identity. Experience of ethnicity in early childhood, within the home, critically marks a sense of belonging. Boyarin and Boyarin, when discussing the process of constructing ethnic identities in childhood, argue: 'Contact with other people who share the name of a given identity and seem to feel organically connected to a community can produce a sense of nostalgia even in one who has never been near the things that that community does' (1993: 704). Home is the symbolic and real place that becomes a synonym to familiarity, intimacy, security and identity against the unknown, the distant and the large. 'Home, of course, needs to be understood in both literal and metaphorical senses. The defense of home is a defense of both the private spaces of intimate social relations and domestic security - the household; as well as of the larger symbolic spaces of neighbourhood and nation - the collective and the community', Silverstone (2004: 442) argues. Media destabilize the role of the home in achieving ontological security. '[B]oth, [the domestic and the collective home] are threatened by the media extension of cultural boundaries: both laterally, as it were, through the globalisation of symbolic space, and vertically through the extension of accessible culture into the forbidden and the threatening. In both cases home has to be defended against material breaches of symbolic security' (Silverstone, 2004: 442). For diaspora, extended cultural boundaries might be enabling for the construction of new and multiple domestic and collective homes. At the same time, and as cultural boundaries stretch, stability becomes less adequate as a synonym for home. Home in the case of diasporic populations is always ambiguous and incomplete. It is never as fixed and permanent as the ideal perception of The Home assumes it to be: private, safe, fixed, a shelter to return to. In a way, this idealization of home does not correspond to any kind of home anywhere in late modernity, where symbolic and real boundaries of space and privacy are blurred (Silverstone, 2004). But in no other case is the change of Home more obvious than in the case of diaspora. The diasporic home is not necessarily synonymous with a house, it is not necessarily singular. Which house would that be anyway? Which one home is home? 
Massey (1993) questions the stable and inward-looking nature of the home and argues that a sense of place does not depend on its stability and purity; rather it depends on its unique position as a point of intersection in a wider context of relations. Nostalgia, strangeness and the sense of loss intensify the efforts of making a house a home (Morley, 1991). The search for ontological security becomes one of the main reasons for reinventing close family relations, relations that often become even more intense in the diaspora than they would ever be in the country of origin. The extensive focus on constructing a diasporic home, along with the relations that it implies - relations among its members, relations to the inside and the outside world that a construct with walls and windows shapes - give home its meanings. Within the home, diasporic identities are constructed as the hierarchy of family relations and the dominant culture of the family shape roles and moral values. Silverstone and Hirsch (1994) note the significance of the domestic in the modern world as a place enhanced, mediated, contained, even constrained by our ever-increasing range of information and communication technologies and the systems and services that they offer the household. Media shape cultural scapes and mediate interpersonal relations and thus domestic hierarchies and moral values. On the one hand, media invade the privacy of the home (Morley, 1991), making it impossible for the insiders to shape their values and lifestyle without the outsiders' intervention. On the other hand, they mediate for the members of the household the experience of the outside world, before going 'out there'. Media produce representations of the world outside the domestic space but also of the home itself (Morley and Silverstone, 1995).

\section{City}

The culturally diverse, and at the same time, segmented urban space is of key relevance in the production of culture, especially since the city brings together intense media production and diversified consumption. Robins (2001) suggests that we should think through the city, instead of through the nation; the city, he argues, is a more useful category of analysis, especially since it allows us to reflect on the cultural consequences of globalisation from another than a national perspective. 'The nation, we may say, is a space of identification and identity, whilst the city is an existential and experimental space' (2001: 87). With reference to London - a reference that can extend to other cosmopoles - Robins argues that in the city people can re-think and re-describe their relation to culture and identity: '(T)he urban arena is about immersion in a world of multiplicity, and implicates us in the dimension of embodied, cultural experience' (2001: 87). City, and especially the culturally diverse and global city, is a symbolic and physical landscape of cultural contestations, of conflict, but also of coexistence of difference. As Massey puts it:

"“Cities' may indeed pose the general "question of our living together" in a manner more intense than many other kinds of places. However, the very fact that cities (like all places) are home to the weavings together, mutual indifferences and outright antagonisms of such a myriad of trajectories, and that this itself has a spatial form which will further mould those differentiations and relations, means that, within cities, the nature of that question - of our living together - will be very differentially articulated." (2005: 169) 
These particular dynamics of the city and of urban life, with its demographic diversity, its cultural differences and its heterogeneity lead to attempts by urban denizens to find representation outside the formal political sphere. Everyday life often becomes the context for seeking a voice and a presence in public life. Politics of expression and representation are exposed in the street and on the walls, in performances and nightlife, but also in local political and cultural activities. Especially the streets, community centres, libraries, schools, pubs and clubs of culturally diverse working class neighbourhoods reveal imaginings and reimagining of belonging which are often distant from the rules and the imagination of the nation and thus leave more space for the emergence and expression of identities that are multiple, diverse and outcomes of close contact with difference. The boundaries of everyday practice and mediated life have less to do with the nation and more with the potentials and restrictions in (i.) connections between the local in the local (e.g. different groups sharing the same locality; experiencing poverty, access to and scarcity of sources); (ii.) links between the local and the transnational (e.g. diasporic connections; translocal networks of cultural production and consumption; networks of kin and of economic and commercial interests); and (iii.) 'the ability to imagine what is not there and to keep hold of that "image"” (Amin and Thrift, 2002: 114).

In addition, the city gives rise to new solidarities and possibly to new forms of community. These solidarities emerge at points of contact between urban subjects who have different origins, possibly different orientations for the future, but importantly they emerge among human subjects who share a common present. As Bachelard argues 'Space is an arrangement (or configuration) of objects that orient inhabitants (or citizens or insiders) towards strangers (or outsiders or aliens) in a way that allows agents to form solidarities, affinities, and identifications (subjectivities) by using contiguous proximity and similarity (spatial relations) or analogy and difference (transpatial relations) as strategies and technologies...These relationships between groups depend on a structured pattern of co-presence and co-absence' (Bachelard in Isin, 2002: 48).

\section{National and Transnational Space}

The nation - which in modernity has been formalized as a nation-state depends on ideologies and practices of clear-cut borders and requires the formation of identities and communities within defined borders and territory (Holton, 1998). There is a key contradiction in the position of the nation in our times. On the one hand, culture and communication become increasingly deterritorialized and transnational, while at on the other hand, the national political boundaries become increasingly reinforced. This condition creates a rupture between the politics of the nation and the human condition within nations and even more so for those human subjects who cross national boundaries, especially through migration. As Beck argues, mediated mobility has transformed 'the experiential spaces of the nation-state from within' (Beck, 2006: 101) (emphasis in original). But the physical contains and grounds the mediated. The mediated 'freedom of flows' is not by definition liberating but contested; it is grounded by the constraining powers of the physical and the national (Bauman, 1998). The 
nation-state aims at sustaining its power and legitimacy based on ideologies of singularity - of singular loyalties, of the singularity of the national space ownership and of clear-cut borders. At the same time, diaspora challenges national ideologies, but it often finds itself trapped in them. The nation-state of origin requires loyalty and commitment, so does the nation-state of settlement. The nation-state in modernity and this has not changed in late modernity as radically as is often claimed - forms its own project of progress and harmony based on social, economic and, inevitably, cultural assimilation of its population. It is in this context that cultural difference - as often expressed in diasporic cultural ideologies and practices - is marginalized, excluded and alienated within countries hosting diasporic populations.

In this context of tension between diaspora and the nation, the latter still keeps its important role in the scheme of diasporic belonging. Even as a source of restrictions and ideological polarization (e.g. expressed in discourses of nationalism, demands for singular loyalty, legitimating of national military power), it should be acknowledged as an element of the diasporic space of identity for at least two reasons. On the one hand, in democratic societies, national law (should) protect (diasporic) minorities from discrimination, racism and exclusion and thus (should) broaden participation in multiethnic societies with consequences for diasporic representation. On the other hand, restrictions, polarizations and exclusions initiated in the actual practices and ideologies of the nation play their part in the construction of identities. Identities are not shaped only through positive and creative processes of participation and communion, but also in processes of exclusion, marginalization and regressive ideologies - expressed in the mainstream ideologies of the country of settlement or of the country of origin, but also voiced from within the diasporic communities.

The national is a space of political and cultural restrictions and of negotiation and establishment of formal rights and duties; it is a space of a constant struggle between processes of diasporic social and cultural inclusion and exclusion. But the space that is almost homologous to diaspora is transnational space, as it emerges in the intense interaction and tense co-dependence with the national context and imaginary. Transnational is not equal to the global, though it does relate to many common uses of the global in the literature. Transnational space acknowledges the development and sustaining of connections and networks across geographical, cultural and political borders (Basch, Schiller and Blanc-Szanton, 1994), while at the same time it recognizes the interconnection and co-existence of the local, the national and the global. The transnational emphasizes the possibility for development of meaningful relations and social formations across borders and through the development of dense networks (Portes, 1997). As such, it is particularly relevant inunderstanding the processes by which migrant and diasporic communities forge and sustain multistranded social relations. The transnational is more meaningful than the global, especially in the context of the present discussion. It recognizes both the possibilities of networks and communities to surpass national boundaries, as well as the continuing significance of the national borders in partly framing and restricting social actions and their meanings. Furthermore, the transnational lacks the utopian connotations often attached to the global, which tend to equate it to the universal. 
It is in the context of transnationalism that contemporary theorizations of diaspora become useful in thinking of continuity, community and attachment across space. While diaspora is a contested concept - having at times implied ethnic homogeneity and identity essentialism - in debates around globalization, transnationalism and communication, diaspora has been re-appropriated to recognize heterogeneity and diversity, transformation and difference (Hall, 1990; Clifford, 1994). While there is a temptation to interpret the often observed attachment of dispersed people with a transnational community as a reproduction of the imagined community of the nation in global scale, the diasporic case is significantly different from both the nation and the primordial bounded community. The diasporic condition has significant particularities, many of which are shaped in the context of globalization. 'Practices of displacement might emerge as constitutive of cultural meanings rather than as their simple transfer or extension', argues Clifford (1997: 3). Diasporic consciousness is not just about being 'Chinese' or 'Greek' or 'British' or 'French' according to people's settlement; 'it is also about feeling global' (1997: 257). Diasporic consciousness, Clifford continues, is about the possibility of gaining 'a sense of attachment elsewhere, to a different temporality and vision, a discrepant modernity' (1997: 257). Diasporic continuity is as much about the imagining of a common origin and a common fate as it is about the transnationalization of possible common imaginings, which are particular and specific to a group but also global in their relevance. Diasporic continuity is about the interrelation between universalism and particularism - it is about the global and the transnational as much as it is about the particular identity and community.

\section{SPACE, IDENTITY AND THE MEDIA}

The intensification of mobility and thus of diasporic scattering, the development of communication technologies and networks across the world and the relocation of diasporic populations in global cities where capitalism thrives are all key conditions of a cosmopolitan condition with reflection to the diasporic formation and change. Massey's discussion of Graham's thesis on the 'mutual constitution' of technology, space and place (2005) is inspiring in arguing about the reconstitution of contemporary cultural and imagined space. As argued, place and space are constantly reshaped as the relation between technologies, practices, and their location is always changing. In the case of diaspora, we see constant mobility, but also changes in directions, quantities and qualities of communication exchange across transnational spaces. Images and sounds of different origins, destinations and flows become part of the everyday emotional and communicational experience of the diaspora. As a consequence, the social relations which are located in place are shaped and shape technologies of communication and of connection. One of the consequences of the available diverse cultural repertoires on the push of a button is the contestation of the mainstream, national and top-down ideologies of identity as equated to national boundedness. The local, the national and the transnational actively intermingle in emerging multi- and de-centred cultural landscapes that emerge in exchanges across borders or outside formal and nationally controlled systems of communication. Such diversity in cultural repertoires exchanged, consumed and constructed, destabilise 
national mediascapes and redefine transnational and local ones. Arguably, the production and consumption of different media, which slip outside the control of the state and their geographical boundedness, form one of the major challenges to bounded and formally constructed political geographies. For diasporic populations and other denizens of culturally diverse societies, living with difference, the possibility of imagining cultural landscapes beyond, next to and vis-à-vis the imagined community of the nation (Anderson, 1983) is now a lived reality.

It is in the context of diasporic scattering and development of networks across the world, especially across global cities that we should study transnational networks and connections in their expressions and implications for diasporic identities and cosmopolitan societies. Massey $(1993 ; 2005)$ also talks about the changing geography where social relations, movements and communication are transformed and come together in places that become unique points of their intersection. Geographical places become meeting places:

"Instead then, of thinking of areas with boundaries around, they can be imagined as articulate movements in networks of social relations and understandings... but where a large proportion of those relations and understandings... are constructed on a far larger scale... And this, in turn, allows a sense of place which is extroverted, which includes a consciousness of its links with the wider world, which integrates in a positive way the global and the local"

(Massey, 1993: 239).

Massey stretches out a basic element of (inter-)spatial meetings - the hybridization of human relations, of identities and of places. The city especially, becomes a hybrid place where distinct and parallel experiences of travel, settlement, and cultural formations meet in a multiplicity of histories which are not bounded in one place but formed through movement in space (Massey, 2005).

\section{Proximity}

An important change that has been emerging through mobility and resettlement is who is close to whom and with what consequences. Changes in distance and proximity can destabilize or reinvent identities and their limits. Meyrowitz's words in regards to who is with (or without) whom are helpful:

“...While we tend to think of our group affiliations simply in terms of who we are, our sense of identity is also shaped by where we are and who is with us. A change in the structure of situations - as a result of changes in media or other factors - will change people's sense of us and them. An important issue to consider in predicting the effects of new media on group identities is how the new medium alters who shares social information with whom. As social information-systems merge or divide, so will group identities" (1985: 54).

The questions of where and with whom highlight the significance of spatial proximity and distance. Diasporization, as combined with intense mediation, has advanced the sense of proximity in two ways: (i.) in relation to increased (mediated) 
proximity among members of diaspora located in various places but occupying a common diasporic (symbolic) space; and (ii.) in relation to the mediated and physical proximity shared among people with different backgrounds, especially in cosmopolitan cities - i.e. the intense juxtapositions of difference in the cosmopolis. In relation to the mediated diasporic proximity across spaces, the level and continuity of contact is unprecedented in human history and this creates possibilities for reinforcing a common sense of belonging. At the same time, the growing and constant flows of information often result into critical reflection and selective engagement with national imagined communities; increased information and interaction remind the members of diasporic groups that the original homeland is not sacred and pure and that the spread populations who share a common origin are not characterized by cultural sameness. Increased exchange of images and sounds from the country of origin and other diasporic people becomes a constant reminder of diversity and of the real and present face of the country of origin and the broader diaspora. The second sense of proximity, which brings close people of different backgrounds - the intense juxtaposition of difference in the cosmopolis - also has important consequences for identity and the sense of belonging for diasporic and other cosmopolitan subjects. Possibly more than any other location, the city brings people, technologies, economic relations, and communication practices into unforeseen constellations and intense juxtapositions of difference (Benjamin, 1997). The intense urban juxtapositions of difference in the unglamorous, and often marginalised and deprived, quarters of the global cities are usually invisible in tourist brochures; they are however locations where the potential of communication technologies to connect people in the locale and across boundaries, in shared attempts to seek citizenship, to find a location in the city and the world, and to shape identity in a cosmopolis are revealed in intensity rarely observed elsewhere.

Outside - and often in contrast - to the national and corporate reactions to territorial identity and formal citizenship, the city becomes a space where creativity and media production turn into cultural and political strategies for seeking recognition and representation, especially among those excluded from other forms of representation in political and cultural life. Some of the tensions observed in the relations between the culturally diverse urban dwellers are the outcome of the conflict between cultural belonging in transnational worlds and the demands to comply with exclusive regimes of citizenship. Urban creativity becomes particularly interesting in this case. Often attached to the tactics of seeking representation outside the restrictive national framework, urban (mediated) cultural production includes various forms of expression on city walls, in local radio stations, in urban music and nightlife cultures. Excluded from citizenship rights, education and Eurocentric and corporate cultures, migrants and members of diasporic groups (especially young people) often engage in alternative forms of (mediated) expression and self-representation. Some of these creative practices are initiated as political acts of opposition to the state or to excluding politics of representation. For example, as graffiti, software piracy and radio piracy are illegal acts, the meanings of such practices are shaped in the context of illegality, opposition or rejection of the politics of the state. The cultural and social locations of such acts and the enactment of these practices by young, usually disenfranchised and minority youth, reflects - if not singularly, at least partly - processes of active opposition to state and corporate cultures that provide them no space for representation 
or respect. Such creative practices sometimes allow urban dwellers to develop a common (plebeian) cosmopolitan language of communication in the locale and across transnational spaces. What we can observe in the above cultural practices is the emergence of cosmopolitan identities which are less about exclusive and bounded belonging but which are as much about the particularity of diaspora, as they are about the co-presence and proximity with various others. The media play a key role in this emerging proximity.

\section{A (new) media world?}

Media can shape discourses and network links of imagined (co-)presences and imaginative mobility as well as what Urry calls 'interpretative tools to make sense of "what would otherwise be disparate and apparently unconnected events and phenomena' (Urry, 2000: 180). As such they reinforce a sense of belonging but also awareness about links and possibilities for links and connections. At the same time, media often project a dominant model of identity as a holistic, essential quality of life. In their ever-presence, they repeatedly project particular perceptions and values that ascertain commonality and community. Media become involved in the everyday construction of images of Us and the Others, while fixing and (re-)broadcasting those images to members and non-members of a group. Electronic media especially enable their taken for grantedness, immediacy and simultaneity in everyday life in their structure and technical form (Silverstone and Hirsch, 1994). Their ever-presence means they get involved in identity construction in multiple ways. In their availability and presence in everyday life, they provide access to distant world, to the dispersed diaspora, to the country of origin. Constant and simultaneous exchanges and images shared across borders play a key role in the reinforcement of a sense of community (Georgiou, 2006). The existence of these media per se does not guarantee the continuity of the relevance of community. Members of diasporas are also consumers; as cosmopolitan subjects they tend to have access to a large number of cultural (mediated) sources to choose from; though their consumption of different media and communication systems, they often become more savvy and more selective (Aksoy and Robins, 2000). Furthermore, the potential users of the media have multiple identities, different lifestyles and their identities are not inescapably dependant on diasporic continuity and belonging. Research (e.g. Gillespie, 1995; Georgiou, 2006; Rigoni, 2005) shows that media can indeed be used in processes of reconfirmation of diasporic identities and specific cultural communities; at the same time - the same research shows - we can observe a growing diversity of diasporic mediascapes, which leads to further diversification of the ways that diasporic subjects relate to communities.

The growing diversification of mediascapes also challenges projections of rigid ideologies of singular identities projected in formal politics but also in national (and sometimes diasporic) media. A key element of the diversified mediascapes unfolds in the streets of cosmopolitan cities, as already discussed above; the city provides space for communication but also for performative identities. Urban pockets become spaces for performative identities, which take their shape around struggles for representation of various cultures, cacophonous aesthetics and diverse interpretations 
and practices of global popular culture, democracy, law and order (even in their direct violation). Such performative identities are often excluded from the mainstream media and the imaginary of national cohesion; they are often treated by the state with uncomfortable inability to understand or as potential threats to the ideology of the nation and western modernity. Performative urban identities increasingly move away from the national imaginary and media and communications become experimental tools in this process. This does not mean that urban appropriations of media and technologies are always safe, democratic and dialogic. The cases when media are used as effective systems to compete with and to contest other cultures, to spread political and religious propaganda and to undermine dialogical communication that takes place in the street exist next to emancipating and democratic media projects. What all projects have in common is that they reflect elements of a dissident cosmopolitanism outside exclusive national zones. Importantly, what we increasingly observe among the newest forms of urban media production is a contestation of national frameworks of belonging, not only in relation to the country of settlement, but also in relation to the country of origin. Projects such as multicultural radio stations, urban art production and experimentations with technologies outside ethnically exclusive spaces reveal new forms of identities that have more to do with cosmopolitan life than with exclusive ethnic and national spheres of belonging.

\section{CONCLUSION}

Mediated and interconnected space becomes a space of contestation, of complex and often conflicting articulations of identity. In having access to various media and to communication technologies that diasporic people can control and manipulate in order to connect to (or disconnect from) individuals and communities in their neighbourhood or in distant places, they provide the ultimate example of the cosmopolitan condition. By being more informed about the politics and the culture of the country of origin, other sections of the diaspora, the country of settlement, or their locality, diasporic individuals and groups can construct a world of critical proximity: they become aware that, either they like it or not, they are not just reflections of their country of origin, they do not just belong to a single group, they are not just located in a territory; thus and inevitably, diasporic identity is lived as multi-positioned in symbolic and geographical spaces. 'High mobility and increased mediation means that 'more and more people are living in a kind of place-polygamy. They are married to many places in different worlds and cultures. Transnational place-polygamy, belonging in different worlds: this is the gateway to globality in one's own life' (Beck, 2002: 24). In addition, and as the contact with others they do not share the same past becomes a constant and daily reality, diasporas show that identity is not only about what is inside a group and it is not only about continuity, but also it is about reinvention of the limits of representation in the social space where these human subjects find themselves. The locations where diasporic subjects find themselves also form a spatial context for redefining their presence as members of new social worlds that demand seeking representation beyond the community. The need to find a place in these new social worlds requires negotiation and development of performed identities that surpass the 
particularity of an inward looking identity. Finally, the relations that develop or are sustained across distance with family, kin, and communities, are more and more networked and mediated, making territorial particularity less significant and spaces of communication more relevant for identity and belonging.

\section{References}

AKSOY Asu, ROBINS Kevin (2000) Thinking Across Spaces: Transnational Television from Turkey, European Journal of Cultural Studies, 3 (3), pp. 343-365.

AMIN Aly, THRIFT Nigel (2002) Cities: Reimagining the Urban, Cambridge, Polity.

ANDERSON Benedict (1983(1991)) Imagined Communities: Reflections On the Origins and Spread of Nationalism, London, Verso.

APPADURAI Arjiun (1996) Modernity at Large: Cultural Dimensions of Globalization, Minneapolis, MN, University of Minnesota Press.

BAUMAN Zygmunt (1998) Globalization: The Human Consequences, Cambridge, Polity Press. BECK Ulrich (2002) The Cosmopolitan Society and its Enemies, Theory, Culture and Society, 19 (1-2), pp. 17-44.

BECK Ulrich (2006) Cosmopolitan Vision, Cambridge, Polity.

BENHABIB Seyla (2004) The Rights of Others: Aliens, Residents and Citizens, Cambridge, Cambridge University Press.

BENJAMIN Walter (1997) One Way Street, London, Verso.

BOURDIEU Pierre (1979) Distinction: A Social Critique of the Judgment of Taste, Harvard, MA, Harvard University Press.

BOYARIN Daniel, BOYARIN Jonathan (1993), Diaspora: Generation and the Ground of Jewish Identity, Critical Inquiry, 19 (4), pp. 693-725.

CALHOUN Craig (1998) Community without Propinquity Revisited: Communications Technology and the Transformation of the Urban Public Sphere, Sociological Inquiry, 68(3), pp. 373-97.

CLIFFORD James (1994) Diasporas, Cultural Anthropology, 9(3), pp. 302-337.

CLIFFORD James (1997) Routes: Travel and Translation in the Late Twentieth Century, Cambridge, MA, Harvard University Press.

COHEN Robin (1997) Global Diasporas: An Introduction, London, UCL Press.

DE CERTEAU Michel (1984) The Practice of Everyday Life, Berkeley, Los Angeles and London, University of California Press.

DELANTY Gerard (2000) Citizenship in the Global Age: Culture, Society and Politics, Buckingham, Open University Press.

GEORGIOU Myria (2006) Diaspora, Identity and the Media: Diasporic Transnationalism and Mediated Spatialities, Cresskill, NJ, Hampton Press.

GIDDENS Anthony (1990) The Consequences of Modernity, Cambridge, Polity.

GILLESPIE Marie (1995) Television, Ethnicity and Cultural Change, London, Routledge.

HALL Stuart (1990) Cultural Identity and Diaspora, in J. Rutherford (ed.), Identity: Community, Culture, Difference, London, Lawrence and Wishart.

HARVEY David (2006) Cosmopolitanism and the Banality of Geographical Evils, British Journal of Sociology, 57(1), pp. 529-564.

HOLTON Robert (1998) Globalization and the Nation-State, London, Macmillan.

ISIN Egin (2002) Being Political: Genealogies of Citizenship, Minneapolis and London, Minnesota University Press. 
LEFEBVRE Henri [with S. ELDEN and E. LEBAS] (2003) Henri Lefebvre: Key Writings, London, Continuum.

MASSEY Doreen (1993) A Global Sense of Place, in A. Gray and J. McGuigan (eds.), Studying Culture: An Introductory Reader, London, Arnold.

MASSEY Doreen (2005) For Space, London, Thousand Oaks, CA, New Delhi, Sage.

MORLEY David (1991) Family Television: cultural Power and domestic Leisure, London, Routledge.

MORLEY David, SILVERSTONE Roger (1995) Communication and Context: Ethnographic perspective on the Media Audience, in K. Bruhn Jensen and N. W. Jankowski (eds.), A Handbook of Qualitative Methodologies for Mass Communication Research, London, Routledge.

PORTES Alejandro (1997) Immigration Theory in the New Century: Some Problems and Opportunities, International Migration Review, 31(4), pp. 799-825.

RIGONI Isabelle (2005) Media and Minorities in Multicultural Europe, Journal of Ethnic and Migration Studies, 31(3), pp. 563-580.

ROBINS Kevin (2001) Becoming Anybody: Thinking Against the Nation and Through the City, City, 5(1), pp. 77-90.

SAID Edward (1985) Orientalism, Harmondsworth, Middlesex, Penguin Books.

SANDERCOCK Leonie (2003) Cosmopolis II: Mongrel Cities in the 21st Century, London, Continuum.

SASSEN Saskia (2001) The Global City: New York, London, Tokyo, Princeton, Princeton University Press.

SCHILlER Nina G., BASCH Linda, BLANC Christina S. (1995) From Immigrant to Transimmigrant: Theorizing Transnational Migration, Anthropological Quarterly, 68(1), pp. 48-63.

SILVERSTONE Roger (1994) Television and Everyday Life, London, Routledge.

SILVERSTONE Roger (1999) Why Study the Media? London, Thousand Oaks, CA, New Delhi, Sage.

SILVERSTONE Roger (2004) Regulation, Media Literacy and Media Civics, Media, Culture and Society, 26(3), pp. 440-449.

SILVERSTONE Roger, HIRSCH Eric (1994) Consuming Technologies: Media and Information in Domestic Spaces, London, Routledge.

URRY John (2000) Sociology Beyond Societies: Mobilities for the Twenty-First Century, London and New York, Routledge.

VERTOVEC Steven (2009) Transnationalism (Key Ideas), London and New York, Routledge.

WERBNER Pnina (1999) Global Pathways: Working Class Cosmopolitans and the Creation of Transnational Ethnic Worlds, Social Anthropology, 7(1), pp. 17-35.

WERBNER Pnina (2008) Anthropology and the New Cosmopolitanism: Rooted, Feminist and Vernacular Perspectives, Berg. 


\title{
Identité, espace et médias : une réflexion sur la construction diasporique
}

\author{
Myria GEORGIOU
}

Cet article propose une approche spatiale de l'identité et de la médiation dans la mesure où, comme il le soutient, cette approche offre un cadre pour appréhender et analyser la construction complexe et mouvante de l'identité dans le monde interconnecté contemporain. Plus précisément, il examine l'importance de la mobilité, des intersections médiées et immédiates, et des juxtapositions de la différence comme des éléments nécessaires à l'analyse des constructions identitaires contemporaines. Ce papier propose une analyse multi-spatiale et argumente sur la matrice spatiale de l'appartenance diasporique. Le cas de la diaspora est choisi comme un cas exemplaire de la formation culturelle dans un monde interconnecté. Comme il est soutenu, la diaspora envisage la mobilité et l'installation des personnes non comme des opposés, non comme des causes et des effets, mais plutôt comme des éléments co-existants dans un monde connecté par des flux et des réseaux. La diaspora représente également un cas exceptionnel de médiation intense, puisque d'une part les réseaux de communication et les échanges d'information se développent à travers différents lieux et, d'autre part, ceux-ci suivent des directions différentes, avec des conséquences pour l'identité et la communauté.

\section{Identity, Space and the Media: Thinking through Diaspora}

\section{Myria GEORGIOU}

This paper proposes a spatial approach to identity and mediation as, it is argued, this approach provides a framework for grasping and analysing the complex and changing formation of identity in current times and in an interconnected world. More specifically, it looks at the significance of mobility, immediate and mediated intersections and juxtapositions of difference as necessary elements of the analysis of current formations of identity. The paper proposes a multi-spatial analysis and looks at the spatial matrix of diasporic belonging in developing the discussion. The case of diaspora is chosen as an exemplary case of cultural formation within an interconnected world. As it is argued, diaspora captures human mobility and (re-)settlement not as opposites, not as cause and effect, but rather as co-existing elements of a world connected through flows and networks. Diaspora also presents an exceptional case of intense mediation, as communication networks and information exchange develop across various locations and they follow different directions with consequences for identity and community. 


\title{
Identidad, espacio y medios de comunicación: pensar a través de la diáspora
}

\author{
Myria GEORGIOU
}

Este artículo propone un acercamiento espacial a la identidad y a la mediación en la medida en que esta aproximación ofrece un marco para aprehender y analizar la construcción compleja y cambiante de la identidad en el mundo interconectado contemporáneo. En concreto, se estudia la importancia de la movilidad, las intersecciones mediadas e inmediatas, y las yuxtaposiciones de la diferencia como elementos necesarios para el análisis de las construcciones identitarias contemporáneas. Este artículo propone un análisis multi-espacial y explica la matriz espacial de la pertenencia diaspórica. El caso de la diáspora es elegido como un caso ejemplar de la formación cultural en un mundo interconectado. Como se defiende en el artículo, la diáspora implica la movilidad y la instalación de personas no como opuestos, ni como causas y efectos, sino más bien como elementos co-existentes en un mundo conectado por flujos y redes. La diáspora representa igualmente un caso excepcional de mediación intensa, porque las redes de comunicación y los intercambios de información no sólo se desarrollan a través de lugares diferentes, sino que además siguen direcciones diferentes, con consecuencias para la identidad y la comunidad. 